\title{
LEGISLATIVE AND COMMUNITY SUPPORT FOR OFFENDER REINTEGRATION IN VICTORIA
}

\author{
LESLEY HARDCASTLE* \\ TERRY BARTHOLOMEW** \\ JOE GRAFFAM ${ }^{* * *}$
}

The status of offender rehabilitation has been influenced by the prevailing social climate, the promotion of ways to improve rehabilitation's efficacy, and the well documented cycling of correctional imperatives. A renewed interest in offender transitions and reintegration has been apparent in recent years and most western correctional systems now feature policies and/or programs that address issues relating to the housing, employment, education and the broader 'resettlement' of offenders. However, this movement of correctional imperatives into the 'social' realm brings considerable challenges. Perhaps most significantly, the achievement of reintegration is dependent on juridical and community support in ways that other sentencing goals are not. Given the array of understandings of what 'reintegration' actually is, the abundance of programs claiming such a focus, and the reliance that reintegrative ideas have on community support, measuring the extent and nature of such support is seen as a useful exercise. With the above in mind, the goal of this paper is to identify legislative and community obstacles to the success of reintegrative ideals and policies. The paper first examines relevant legislation for references to reintegrative notions, finding a legislative ambivalence about such ideas. It then presents findings from a Victoria-wide survey of community views about the reintegration of ex-offenders. Participants in the community survey $(n=$ 2635) were asked for their views about sentencing objectives, and the nature of their support for employment and housing initiatives. The results showed low levels of overall support for reintegration, with numerous more

* PhD, Research Fellow, School of Psychology, Deakin University, Burwood, Victoria, Australia.

** PhD, Senior Lecturer, School of Psychology, Deakin University, Burwood, Victoria, Australia.

*** Professor, Director, Centre for Mental Health and Wellbeing Research, Deakin University, Burwood, Victoria, Australia. 
subtle distinctions being evident. The data also identify numerous areas where reintegrative programs are likely to be more readily accepted. The findings also indicate a need for targeted research into the correlates of community readiness for specific aspects of offender reintegration, and underlines the need for community education about the social implications of effective reintegration policies for urban, regional and rural communities.

\section{INTRODUCTION}

Offender rehabilitation has been a key justice system objective for more than two decades. The models of rehabilitation that have dominated correctional policies have been those that target psychological deficits and abundances. However, in the face of widespread dissatisfaction with the inability of punishment and rehabilitation to reduce reoffending to levels that justify their sizeable costs, there has been a renewed focus on broader psychosocial and reintegrative policies that focus on ex-offender ${ }^{1}$ (re)adjustment to the community. This interest has been expressed via a plethora of correctional programs that focus on capacity building, resettlement, housing, employment, and education for offenders. This trend has also seen increased use of the term 'reintegration' in the corrections discourse, and attempts to place it within a theoretical framework. ${ }^{2}$

The meaning of the term 'reintegration' itself is contentious. Although it is commonly used as a synonym for rehabilitation, it is more usefully positioned within a different paradigm. The forensic psychological concept of rehabilitation is based on a medical model encompassing disease/disorder, diagnosis/assessment, and treatment. It focuses on the individual, and on 'making good' the deficits and criminogenic needs of offenders. Reintegration, on the other hand, focuses on the psychosocial transition from offender to law-abiding citizen, and is concerned with issues such as poverty, education, family and community support, accommodation, disenfranchisement, stigma and labelling. The term 'reintegration', as it is commonly used in the Australian context, denotes social inclusion, or

\footnotetext{
${ }^{1}$ While technically, an offender who has returned to the community is an 'ex-offender', the term 'offender' is understood as someone who has offended, and is used in this sense hereafter.

${ }^{2}$ See, eg, John Braithwaite, Crime, Shame, and Reintegration (Cambridge University Press, 1989); Tony Ward and Mark Brown, 'The Good Lives Model and Conceptual Issues in Offender Rehabilitation' (2004) 10 Psychology, Crime \& Law 243-57; Shadd Maruna, Russ Immarigeon and Thomas LeBel, 'Ex-offender Reintegration: Theory and Practice' in Shadd Maruna and Russ Immarigeon (eds), After Crime and Punishment: Pathways to Offender Reintegration (Willan Publishing, 2004) 3-26.
} 
productive membership of the community. Baldry, McDonnell, Maplestone and Peters have defined social reintegration as the introduction/return of the ex-prisoner to functional, personally fulfilling and responsible participation in wider society ... [comprising] ... factors such as secure housing, adequate income, and supportive relationships. ${ }^{3}$

It is well established that initiatives that assist offenders with employment, education, housing and other pro-social interactions have significant impacts on reoffending and system return rates. ${ }^{4}$ As a result, western correctional systems have seen many programs emerge, which seek to address such concerns. ${ }^{5}$ Indeed, an informal audit undertaken by the authors identified more than 30 Victorian transition programs that seek to assist offenders and ex-prisoners with issues relating to housing and employment, with many more across other Australian jurisdictions. Such initiatives represent a positive step. However, as was earlier noted, reintegration depends on community support and engagement if it is to be successful and numerous studies have shown that

${ }^{3}$ Eileen Baldry, Desmond McDonnell, Peter Maplestone and Manu Peeters 'Ex-prisoners and Accommodation: What Bearing Do Different Forms of Housing Have on Social Reintegration for Ex-prisoners?' (Paper presented at the Housing, Crime and Stronger Communities Conference, Melbourne, 6-7 May 2002) 2.

${ }^{4}$ Maria Borzycki and Eileen Baldry, Promoting Integration: The Provision of Prisoner Postrelease Services (Australian Institute of Criminology, 2003); Victor Callan and John Gardner, Vocational Education and Training Provision and Recidivism in Queensland Correctional Institutions (National Centre for Vocational Education Research, 2005); Maria Borzycki, Interventions for Prisoners Returning to the Community (2005) Australian Government, Attorney-General's Department <http://www.ag.gov.au/agd/WWW/ncphome.nsf/AllDocs /97F159B523B4BA72CA256FF500064FB7?OpenDocument>; Joe Graffam and Lesley Hardcastle (2007) 'Ex-offenders and the Employment Connection: Assistance Plus Acceptance' in Susan Dawe (ed), Vocational Education and Training for Adult Prisoners and Offenders in Australia: Research Readings Adelaide (National Centre for Vocational Education, 2007); Joe Graffam, Alison Shinkfield, Barb Lavelle and Wenda McPherson, 'Variables Affecting Successful Integration as Perceived by Offenders and Professionals' (2005) 40 Journal of Offender Rehabilitation 147-71; Joe Graffam, Alison Shinkfield, Stephen Mihailides and Barb Lavelle, Creating a Pathway to Reintegration: The Correctional Services Employment Pilot Program (CSEPP) Evaluation Report (Victorian Department of Justice, 2005).

${ }^{5}$ Robert Sampson, Stephen Raudenbush and Felton Earls 'Neighborhoods and Violent Crime: A Multilevel Study of Collective Efficacy’ (1997) 277 (no 5328) Science 918; Charis Kubrin and Eric Stewart, 'Predicting Who Reoffends: The Neglected Role of Neighbourhood Context in Recidivism Studies' (2006) 44(1) Criminology 165; Joan Petersilia, 'What Works in Prisoner Reentry? Reviewing and Questioning the Evidence' (2004) 68(2) Federal Probation 4-8; Anthony Thompson, Releasing Prisoners, Redeeming Communities: Reentry, Race, and Politics (New York University Press, 2008); Jeremy Travis, 'But They All Come Back: Rethinking Prisoner Reentry' (2001) 5(3) Corrections Management Quarterly 23-33; Douglas Young, Faye Taxman and James Byrne, Engaging the Community in Offender Reentry (2003) <http://www.nicic.org/Library/019109>. 
the community is far from amenable to reintegrative ideals. For a policy and program direction that emphasises readjustment via access to social resources, community opposition represents a significant obstacle.

One of the ways that community support for reintegrative ideas could be enhanced or even focused is via the law. If legal authority makes clear statements about the purpose and role of reintegration (for example, as a goal of sentencing alongside more established goals such as punishment, deterrence, and rehabilitation), judicial, correctional and community understandings would be enhanced, policies would be provided with crucial guidance, and programs would more likely be supported. As part of this study's goal of identifying obstacles to the success of reintegrative ideas, an informal audit of Australian legal authority was undertaken. The purpose here was to note references to reintegration and related ideas, in order to see how such concepts are enacted.

A screening of those Acts of the Australian states and territories that relate to children/young people, corrections, crime and sentencing ${ }^{6}$ revealed a number of findings. Reintegration per se is not included as a goal of sentencing for adult offenders in any Australian jurisdiction. Rehabilitation, on the other hand, is cited as a goal of sentencing in six of the eight Australian jurisdictions (ACT, NSW, NT, Qld, SA and Vic). Western Australia and Tasmania do not mention either reintegration or rehabilitation as goals of sentencing for adults.

However, there are references to reintegration as a goal of sentencing for juvenile offenders in all Australian jurisdictions. Queensland, the Northern

\footnotetext{
${ }^{6}$ The following Acts were surveyed:

Victoria: Children, Youth and Families Act 2005; Corrections Act 1986; Sentencing Act 1991;

ACT: Crimes (Sentencing) Act 2005; Corrections Management Act 2007; Crimes (Sentence Administration) Act 2005; Crimes (Restorative Justice) Act 2004; Children and Young People Act 2008; Rehabilitation of Offenders (Interim) Act 2001;

Northern Territory: Sentencing Act; Prisons (Correctional Services) Act; Youth Justice Act;

New South Wales: Drug Court Act 1998; Compulsory Drug Treatment Correctional Centre Act 2004; Young Offenders Act 1997; Criminal Procedure Act 1986; Crimes (Sentencing Procedure) Act 1999; Crimes (Administration of Sentences) Act 1999; Children (Criminal Proceedings) Act 1987;

Queensland: Corrective Services Act 2006; Drug Court Act 2000; Child Protection (Offender Prohibition Order) Act 2008; Juvenile Justice Act 1992; Penalties and Sentences Act 1992;

South Australia: Young Persons Act 1993; Criminal Law (Sentencing) Act 1988; Tasmania: Sentencing Act 1997; Corrections Act 1997; Youth Justice Act 1997;

Western Australia: Prisons Act 1981; Sentence Administration Act 2003; Sentencing Act 1995; Young Offenders Act 1994.
} 
Territory, and New South Wales make explicit references to the importance of reintegrating juvenile offenders, while Western Australia, Tasmania, Victoria, South Australia, and the Australian Capital Territory allude to reintegration as a goal of sentencing for juvenile offenders. For example, there are references to promoting social responsibility in young offenders, to the importance of strengthening family ties, continuing educational or vocational training, and preserving the racial, ethnic and cultural identity of the juvenile offender. Similarly, in the majority of jurisdictions' legislation, there are references to the importance of employment, minimising stigma, access to accommodation, reducing financial hardship, reparation, minimising secondary deviance and enhancing social and/or life skills, albeit for juvenile offenders.

The selective nature of this support for reintegrative ideals is compounded when it is noted that this legal discourse also uses the concepts of rehabilitation and reintegration interchangeably. For example, rehabilitation is variously referred to as vocational and educational courses, employment, and as being assisted by the family. Similarly, Victorian legislation makes several references to reintegrative strategies without identifying them as such. For example, the Sentencing Act 1991 refers to the importance of considering social history, education, employment, and financial circumstances, but does not place these considerations in a reintegrative framework. ${ }^{7}$ Similarly, the Corrections Act 1986 (Vic) emphasises the rights of offenders to participate in education in prison educational and vocational training, and employment; ${ }^{8}$ the strengthening and maintaining of family and community ties; ${ }^{9}$ and the need for personal development of the offender, ${ }^{10}$ again without providing a reintegrative context.

Finally, the Children, Youth and Families Act 2005 (Vic) refers to the importance of strengthening and maintaining family and community ties; preserving cultural and spiritual identity; and providing access to health and educational services, to accommodation, to vocational training and to employment; ${ }^{11}$ and enabling a young offender to develop into a socially responsible member of society, ${ }^{12}$ but does not provide any guidance about the ethos that may underlie such clauses.

\footnotetext{
${ }^{7}$ Sentencing Act 1991 (Vic) s 18ZQ(4).

${ }^{8}$ Corrections Act 1986 (Vic) s 47(1)(o).

${ }^{9}$ Corrections Act 1986 (Vic) s 57B(1)(b), s 57B9(1).

${ }^{10}$ Corrections Act 1986 (Vic) s 47.

${ }^{11}$ Children, Youth and Families Act 2005 (Vic) s 362(1).

${ }^{12}$ Children, Youth and Families Act 2005 (Vic) s 405(d).
} 
This brief overview indicates that, although reintegrative concepts are evident in the legislation, they do not have the status of other correctional imperatives such as rehabilitation, deterrence or punishment. In addition, the reader of such legal authority is not provided with any guidance as to the basis and purpose of such inclusions, and there is conceptual and definitional fogginess surrounding them. This situation presents an obstacle for the aforementioned range of reintegrative programs currently running in Victoria. Piquero and Steinberg, ${ }^{13}$ who investigated public attitudes to the rehabilitation of juvenile offenders, noted the importance of positive attitudes as providing an 'ideological space for policy initiatives', ${ }^{14}$ and this may be lacking here. The identified omissions and vagaries mean that it is difficult for reintegrative ideas to be listed as primary sentencing considerations at the judicial level, and that correctional policies are not able to cite legislative direction and support. Further downstream, these issues in the legal authority are likely to affect funding for programs, as well as referrals to them.

Another forum where this legislative ambivalence is likely to have an impact is the community itself. Knowledge plays an important part in constructing community attitudes about a range of justice issues, and it has already been noted that reintegrative ideas are dependent on community support in ways that other sentencing goals are not. Questions about whether the law can (or should) lead or follow public opinion raise jurisprudential issues that are complex and far beyond the scope of this paper. In this context, it is sufficient to note that the two are linked and the links may not always be as presumed. For example, in their investigation of the American public's attitudes to increasingly punitive policies, Cullen et $\mathrm{al}^{15}$ found many contradictions in views about sentencing. They characterised public support for get-tough policies as 'mushy' rather than rigid, and noted that 'the public shows a tendency to be both punitive and progressive, wishing the correctional system to achieve the diverse missions of doing justice, protecting public safety, and reforming the wayward'. ${ }^{16}$

In general, studies that have sought to explicate community views about justice practices have found that the public believes sentences are too lenient, that the judiciary are out of touch with community views and that crime is on

\footnotetext{
13 Alex Piquero and Lawrence Steinberg, 'Public Preferences for Rehabilitation versus Incarceration of Juvenile Offenders' (2010) 38(1) Journal of Criminal Justice 1-6.

${ }^{14}$ Ibid 189.

${ }^{15}$ Francis Cullen, Bonnie Fisher and Brandon Applegate, 'Public Opinion about Punishment and Corrections' (2000) 27 Crime and Justice: A Review of Research 1.

${ }^{16}$ Ibid 2.
} 
the increase. ${ }^{17}$ Australian studies of public attitudes to crime and sentencing have found similarly. ${ }^{18}$ Although, in the abstract, the public thinks that sentences are too lenient, it does favour rehabilitation and community-based sentences over prison and punishment for juvenile and first time offenders. An obvious question emerges here about whether these selective applications of redemptive ideas can be extrapolated to the area of reintegrative policies and practices.

With the exception of Canadian studies of community attitudes to early release of offenders, ${ }^{19}$ and the study conducted by Applegate and colleagues in Ohio of community attitudes to rehabilitation programs, ${ }^{20}$ there has been no specific research into community attitudes to the reintegration of offenders.

${ }^{17}$ Mike Hough and Julian Roberts, Attitudes to Punishment: Findings from the British Crime Survey (Home Office Research and Statistics Directorate, 1998); Catriona Mirrlees-Black, 'Improving Public Knowledge about Crime and Punishment' in Julian Roberts and Mike Hough (eds), Changing Attitudes to Punishment (Willan Publishing, 2002) 184-97; Judy Paulin, Wendy Searle and Trish Knaggs (2003) Attitudes to Crime and Punishment: A New Zealand Study - December 2003 (Ministry of Justice, New Zealand, 2003).

${ }^{18}$ See, eg, Karen Gelb, Measuring Public Opinion about Sentencing Melbourne (Sentencing Advisory Council, 2008); Karen Gelb, More Myths and Misconceptions (Sentencing Advisory Council, 2008); David Indermaur and Lynne Roberts, 'Perceptions of Crime and Justice' in Shaun Wilson, Gabrielle Meagher, Rachel Gibson, David Denemark and Mark Western (eds), Australian Social Attitudes: The First Report (UNSW Press, 2005) 141; David Indermaur and Lynne Roberts, 'Confidence in the Criminal Justice System' in Trends \& issues in crime and criminal justice No 387 (Australian Institute of Criminology, 2009); Holly Johnson, Crime Victimisation in Australia : Key Results of the 2004 International Crime Victimisation Survey (Australian Institute of Criminology, 2004); Craig Jones, Don Weatherburn and Katherine McFarlane, 'Public Confidence in the New South Wales Criminal Justice System' (2008) 118 Crime and Justice Bulletin: Contemporary Issues in Crime and Justice; Lynne Roberts and David Indermaur, 'Predicting Punitive Attitudes in Australia' (2007) 14(1) Psychiatry, Psychology and Law 56-65; Lynne Roberts and David Indermaur, What Australians Think about Crime and Justice:Rresults from the 2007 Survey of Social Attitudes (Australian Institute of Criminology, 2009); Victorian Community Council Against Violence, Community Knowledge and Perceptions of Sentencing in Victoria: A Report on the Findings of the Consultations (Victorian Community Council Against Violence, 1997); John Walker, Mark Collins and Paul Wilson (1987) 'How the Public Sees Sentencing: An Australian Survey' in Trends \& Issues in Crime and Criminal Justice No 4 (1987) $<$ http://www.aic.gov.au/publications/tandi/tandi2004.html>; Paul Wilson, John Walker and Satyanshu Mukherjee, 'How the Public Sees Crime: An Australian Survey' in (1986) 2 Trends and Issues in Crime and Criminal Justice.

19 Jennifer Cumberland and Edward Zamble, 'General and Specific Measures of Attitudes toward Early Release of Criminal Offenders' (1992) 24(4) Canadian Journal of Behavioural Science 442-55; Edward Zamble, 'Public Support for Criminal Justice Policies: Some Specific Findings' (1990) 2 Forum on Correctional Research 14-19.

${ }^{20}$ Brandon Applegate, Francis Cullen and Bonnie Fisher, 'Public Support for Correctional Treatment: The Continuing Appeal of the Rehabilitative Ideal' (1997) 77(3) Prison Journal 237-8. 
However, a number of studies have drawn conclusions about the level of people's support for rehabilitation based on their views of punishment and the purposes of sentencing, and this may or may not present accurate portrayals. ${ }^{21}$

Proponents of community based models of reintegration such as restorative justice, ${ }^{22}$ argue for a reciprocal relationship between the community and offenders. This would enable offenders to reconstruct prosocial identities, participate in civic life and strengthen social ties, thus reducing reoffending beyond the limited extent that is being achieved by rehabilitation and punishment. In the context of the above discussion about increased attention to reintegrative ideas in correctional programing and the ambivalent legislative position in this area, the second component of this study sought to identify the extent and nature of support for reintegration in the Victorian community.

The reintegrative domains of housing and employment were chosen as a focus, with questions about possible differences between 'in principle' support and more concrete preparedness to take part in reintegrative endeavours. While an 'in principle' support for social policies is always desirable, unless the community take their support for reintegration to the next level and express a willingness to work with and/or live near offenders, such policies will be ineffective. Community attitudes regarding these issues tend to follow the 'not in my backyard' (NIMBY) phenomenon ${ }^{23}$, where the community supports a cause in principle, but not in close proximity. Martin and Myers, ${ }^{24}$ for example, found that, while communities may support the

${ }^{21}$ See, eg, Francis Cullen, Jennifer Pealer, Bonnie Fisher, Brandon Applegate and Shannon Santana, 'Public Support for Correctional Rehabilitation in America: Change or Consistency?' in Julian Roberts and Mike Hough (eds), Changing Attitudes to Punishment (Willan Publishing, 2002) 28-147; K Devine, The Age of Criminal Responsibility: Community Attitudes and Developmental Trends (PhD Thesis, Deakin University, 2006); Christopher Hartney and Susan Marchionna, Attitudes of US Voters toward Nonserious Offenders and Alternatives to Incarceration (National Council on Crime and Delinquency, 2009); Barry Krisberg, Jessica Craine and Susan Marchionna, Attitudes of Californians toward Effective Correctional Policies (National Council on Crime and Delinquency, 2004).

${ }^{22}$ See, eg, Gordan Bazemore and Carsten Erbe, 'Reintegration and Restrorative Justice: Towards a Theory and Practice of Informal Social Control and Support' in Shadd Maruna and Russ Immarigeon (eds), After Crime and Punishment (Willan Publishing, 2004); Gordan Bazemore and Jeanne Stinchcomb, 'A Civic Engagement Model of Reentry: Involving Community through Service and Restorative Justice' (2004) 68(2) Federal Probation 14-24; Tony Ward and Robyn Langlands, 'Repairing the Rupture: Restorative Justice and the Rehabilitation of Offenders' (2009) 14(3) Aggression and Violent Behavior 205.

${ }^{23}$ Michael Dear, 'Understanding and Overcoming the NIMBY Syndrome' (1992) 58(3) Journal of the American Planning Association 288.

${ }^{24}$ Randy Martin and David Myers, 'Public Response to Prison Siting' (2005) 32(2) Criminal Justice and Behaviour 143. 
functioning of the criminal justice system, they oppose the facilities, such as prisons, when they are in close proximity to their community. Decreases in tolerance and comfort levels have been found to be caused by the fear of increased crime in the immediate community.

Gaps and vagaries in the relevant legal authority have already been highlighted as a potential obstacle to the success of reintegrative initiatives; the question to be addressed at this stage is whether community views represent another such barrier. This study investigated levels of community support for housing and employment-related issues for offenders, with a specific focus on seeking to identify whether there are types of offence, offenders and/or correctional responses that enhance the community's preparedness to play a role in reintegrative efforts.

\section{METHOD}

In 2009/2010, the Victorian community was surveyed about its attitudes to the reintegration of offenders. The final sample comprised 2635 participants (representing a response rate of approximately 20 per cent) who responded to a questionnaire that was mailed to 12000 randomly selected Victorian residents. The responding sample was generally representative of the Victorian community in relation to sex, language spoken at home, and education level, but those over the age of 54 were over represented (see Table 1 ), and responses were only received from 70 per cent of Victorian postcodes.

\section{Table 1}

Comparison of Victorian ABS Data with Study Sample on Age ${ }^{25}$

\begin{tabular}{|r|r|r|}
\hline Age categories & Victorian pop'n (\%) & \multicolumn{1}{|c|}{ Sample (\%) } \\
\hline 18-24 years & 8.7 & 7.8 \\
\hline 25-54 years & 38.7 & 45.9 \\
\hline 55-64 years & 9.8 & 23.3 \\
\hline 65+ years & 13.4 & 22.7 \\
\hline
\end{tabular}

Source: ABS (2006)

Note. This study was sent to people aged 18 and over.

\footnotetext{
${ }^{25}$ Australian Bureau of Statistics, Population by Age and Sex, Australian States and Territories (2006) <http://www.abs.gov.au/ausstats/abs@.nsf/mf/3101.0>
} 
Among many other questions relating to the justice system, the survey asked participants to rate their level of support for the employment and housing of offenders, and their views about how goals of sentencing should be prioritised. These are the survey components reported in this paper.

\section{A Goals of Sentencing}

Participants were asked to prioritise a list of seven sentencing goals. These included punitive (for example, 'to punish offenders'), rehabilitative ('to rehabilitate offenders'), and reintegrative goals ('to help offenders live productive lives after they have served their sentence'). The supplied scale required responses that ranged between 'high priority' $=7$, to 'low or no priority' $=1$.

\section{B The Employment and Housing of Offenders}

Questions about these reintegrative domains covered two dimensions: 'proximity' (that is, preparedness to engage with offenders) and 'policy' (that is, views about the government providing employment and housing assistance to offenders). In relation to the issue of proximity, participants were asked how comfortable they would feel 'working with' or 'living near' an offender. At the policy level, they were asked about the extent to which they agreed with the government assisting offenders to find and keep employment and housing. Respondents were first asked for their 'in principle/hypothetical' level of support for the employment and housing of a person with a criminal record, and then for their support when given additional information about the offender's offence (for example, 17 offences listed), the offender's correctional history (for example, participation in correctional program, kind of sentence, whether single or multiple offender), and the offender's personal characteristics (for example, age, gender, attitude to reform). Again, participants were asked to indicate their level of support on a scale from $1=$ 'disagree strongly' to 7 'agree strongly'.

\section{RESULTS}

\section{A Goals of Sentencing}

In order to determine the Victorian community's relative support for a reintegrative sentencing goal, participants were asked to prioritise a supplied list of sentencing goals. Participants rated the goal 'To make the community 
safer' as the highest priority, with the goals of 'rehabilitating offenders' and 'helping offenders live productive lives after they have served their sentence' (reintegration) being ranked the lowest. Table 2 presents the means (M) and standard deviations $(S D)$ for the seven goals presented (scores are out of seven).

Table 2

Average priority scores attributed to the listed sentencing goals

\begin{tabular}{|l|r|r|}
\hline Sentencing goals - in order of priority & M & \multicolumn{1}{|c|}{ SD } \\
\hline To make the community safer & 6.33 & 1.28 \\
\hline To deter the offender from committing further crimes & 5.99 & 1.41 \\
\hline To punish offenders & 5.96 & 1.62 \\
\hline To act as an example / to deter others from committing crimes & 5.70 & 1.58 \\
\hline To provide a measure of the seriousness of different crimes & 5.49 & 1.77 \\
\hline To rehabilitate offenders & 5.29 & 1.84 \\
\hline $\begin{array}{l}\text { To help offenders live productive lives after they have served } \\
\text { their sentence }\end{array}$ & 4.90 & 2.02 \\
\hline
\end{tabular}

Participants clearly distinguished between the goals of sentencing, rating safety/deterrence-based goals as significantly more important than rehabilitative and reintegrative ones. A one-way repeated measures ANOVA with pairwise comparisons was conducted to ascertain whether there were statistically significant differences between participants' level of support for the goals of sentencing. Results indicated significant differences between the priority scores given to the goals, $F(4,11242)=386.04, p<.001$. Post hoc tests revealed that participant ratings on all sentencing goals differed significantly from each other $(p<.001)$, except between 'to deter the offender' and 'to punish'.

\section{B Attitudes to the Employment and Housing of Offenders}

Consistent with the above, results in relation to the reintegrative domains of housing and employment indicated average to moderate support. When asked 
to indicate their level of comfort working with and living near an offender ('proximity' items), participants reported low levels of comfort. This pattern was repeated in questions relating to support for government assistance ('policy' questions), with participants being slightly more accepting of government employment initiatives than housing ones. The levels of support for both domains at the proximity and policy level are presented in Table 3 (scores are out of seven).

\section{Table 3}

Average levels of support for employment and housing at the proximity and policy levels

\begin{tabular}{|l|c|c|c|c|}
\cline { 2 - 5 } \multicolumn{1}{c|}{} & \multicolumn{2}{c|}{$\begin{array}{c}\text { Proximity - potential } \\
\text { contact }\end{array}$} & \multicolumn{2}{c|}{$\begin{array}{c}\text { Policy - gov't support } \\
\text { for }\end{array}$} \\
\cline { 2 - 5 } \multicolumn{1}{c|}{} & Mean & $S D$ & Mean & SD \\
\hline Employment & 3.87 & 1.54 & 4.74 & 1.83 \\
\hline Housing & 3.31 & 1.55 & 4.11 & 1.87 \\
\hline
\end{tabular}

These average scores were significantly different from each other $F(3,5493)$ $=486.96, p<.001$.

When given additional information about the offender's offence, levels of support in both of the employment and housing domains were significantly lower than the above detailed 'in principle/hypothetical' support scores. This held true for all offence types provided. Any time an offence was named, participant support for reintegration was lower than when a non-offence specific question about support was made. As is evident from Tables 4 and 5, even the offence type that respondents reported most policy acceptance for (ie, domestic violence, $M=4.13$ ), received lower support than did the 'in principle hypothetical' offender. Similar trends were evident in relation to proximity-related issues, indicating that any information about the actual offence causes a significant change in respondents' support for reintegrative ideas. 
Table 4

Levels of support for employment when the offence is specified and not specified

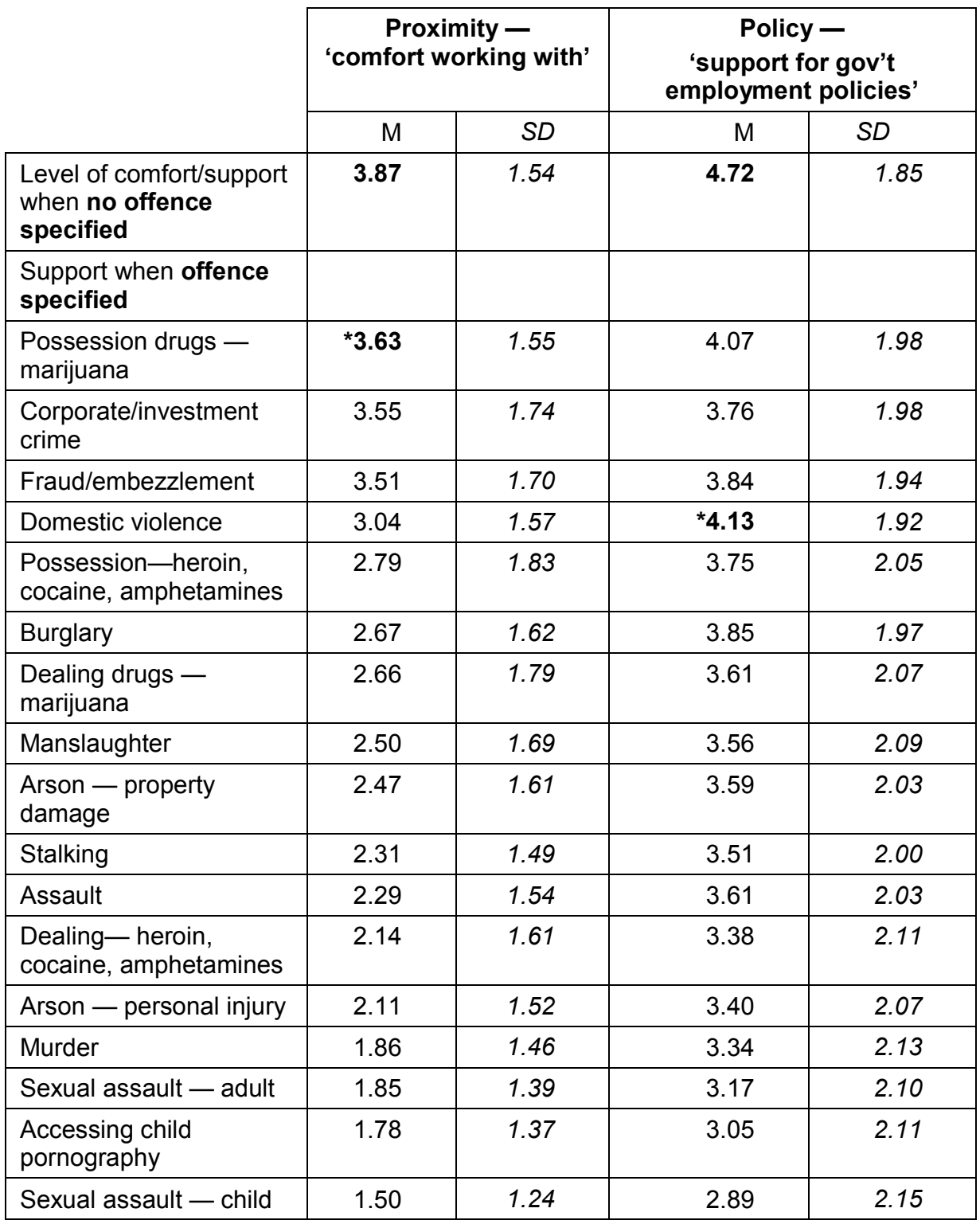

* The highest means when the offence was specified. 
One-way repeated ANOVAs found that average levels of comfort about working with offenders who had committed specific crimes differed significantly, $F(8,19249)=918.23, p<.001$, as did mean levels of support for government employment policies, $F(8,18278)=444.09, p<.001$.

\section{Table 5}

Levels of support for housing when the offence is specified and not specified

\begin{tabular}{|c|c|c|c|c|}
\hline & \multicolumn{2}{|c|}{$\begin{array}{l}\text { Proximity - } \\
\text { 'comfort living near' }\end{array}$} & \multicolumn{2}{|c|}{$\begin{array}{l}\text { Policy - 'support } \\
\text { for gov't housing } \\
\text { policies' }\end{array}$} \\
\hline & $\mathrm{M}$ & $S D$ & $\mathrm{M}$ & $S D$ \\
\hline $\begin{array}{l}\text { Level of comfort / support when } \\
\text { no offence specified }\end{array}$ & 3.30 & 1.55 & 4.13 & 1.89 \\
\hline \multicolumn{5}{|l|}{ Support when offence specified } \\
\hline Corporate/investment crime & *4.04 & 1.75 & 3.41 & 1.89 \\
\hline Fraud/embezzlement & 4.02 & 1.71 & 3.44 & 1.87 \\
\hline Possession-marijuana & 3.22 & 1.87 & 3.45 & 1.96 \\
\hline Domestic violence & 2.81 & 1.64 & *3.58 & 1.91 \\
\hline $\begin{array}{l}\text { Possession -heroin, cocaine, } \\
\text { amphetamines }\end{array}$ & 2.43 & 1.67 & 3.21 & 2.00 \\
\hline Burglary & 2.09 & 1.39 & 3.21 & 1.95 \\
\hline Dealing drugs - marijuana & 2.27 & 1.61 & 3.09 & 2.01 \\
\hline Manslaughter & 2.37 & 1.64 & 3.17 & 2.05 \\
\hline Arson - property damage & 2.04 & 1.38 & 2.99 & 1.98 \\
\hline Stalking & 2.16 & 1.42 & 3.17 & 2.00 \\
\hline Assault & 2.06 & 1.41 & 3.10 & 1.97 \\
\hline $\begin{array}{l}\text { Dealing - heroin, cocaine, } \\
\text { amphetamines }\end{array}$ & 1.87 & 1.43 & 2.93 & 2.03 \\
\hline Arson - personal injury & 1.85 & 1.33 & 2.92 & 2.01 \\
\hline Murder & 1.77 & 1.38 & 3.05 & 2.08 \\
\hline Sexual assault - adult & 1.71 & 1.29 & 2.91 & 2.07 \\
\hline Accessing child pornography & 1.73 & 1.28 & 2.86 & 2.09 \\
\hline Sexual assault - child & 1.41 & 1.11 & 2.76 & 2.14 \\
\hline
\end{tabular}

* The highest means when offence was specified.

Further to the results presented in Table 5, a one-way repeated ANOVA indicated that average levels of comfort about living near offenders who had 
committed different crimes differed significantly, $F(7,17635)=1275.85$, $p<.001$. The result was similar in the realm of policy, with average levels of support for government housing assistance differing across crime types, $F(7$, $16406)=299.56, p<.001$.

Participants reported the highest levels of proximity acceptance for offenders convicted of corporate/investment crime and fraud/embezzlement, although it must be noted that these average scores were still low, ie on or one point below the mid point on the 7 point scale. For policy the highest levels of support were domestic violence, possession of marijuana, corporate/investment crime, and fraud/embezzlement, in that order. In all conditions, the crimes that received the lowest level of acceptance were sexual offences.

When participants were given information about an offender's criminal justice history (aside from their index offence), a pattern similar to the effect of offence type emerged. For employment and housing, proximity and policy, participants were most prepared to support offenders who had completed rehabilitation and education/training programs, and least supportive of those who had committed multiple crimes. Table 6 presents the mean scores for the most and least supported correctional histories. Only the highest and lowest means are included.

\section{Table 6}

Levels of support for housing and employment (at the proximity and policy levels) when details about the offender's correctional history were provided

\begin{tabular}{|l|c|c|c|c|}
\cline { 2 - 5 } \multicolumn{1}{c|}{} & \multicolumn{2}{c|}{$\begin{array}{c}\text { Proximity - } \\
\text { Comfort about } \\
\text { potential contact }\end{array}$} & $\begin{array}{c}\text { Policy - } \\
\text { Support for gov't } \\
\text { policies }\end{array}$ \\
\cline { 2 - 6 } & $\mathrm{M}$ & $\mathrm{SD}$ & $\mathrm{M}$ & $\mathrm{SD}$ \\
\hline $\begin{array}{l}\text { Support for employment when no } \\
\text { correctional history specified }\end{array}$ & $\mathbf{3 . 8 8}$ & 1.54 & $\mathbf{4 . 7 5}$ & 1.83 \\
\hline $\begin{array}{l}\text { Support for employment when } \\
\text { correctional history specified }\end{array}$ & & & & \\
\hline Offence-related rehabilitation & $\mathbf{4 . 1 8}$ & 1.57 & $\mathbf{4 . 8 2}$ & 1.77 \\
\hline Education / training program & 4.13 & 1.60 & 4.79 & 1.77 \\
\hline Multiple crimes & 2.51 & 1.79 & 3.69 & 2.05 \\
\hline & & & & \\
\hline $\begin{array}{l}\text { Support for housing when no correctional } \\
\text { history specified }\end{array}$ & $\mathbf{3 . 3 3}$ & 1.54 & $\mathbf{4} .15$ & 1.88 \\
\hline
\end{tabular}




\begin{tabular}{|l|l|l|l|l|}
\hline $\begin{array}{l}\text { Support for housing when correctional } \\
\text { history specified }\end{array}$ & & & & \\
\hline Offence-related rehabilitation & ${ }^{*} \mathbf{3 . 8 2}$ & 1.57 & ${ }^{*} 4.32$ & 1.77 \\
\hline Education/training program & 3.82 & 1.59 & 4.31 & 1.84 \\
\hline Multiple crimes & 2.31 & 1.54 & 3.37 & 2.01 \\
\hline
\end{tabular}

* The highest means when correctional history was specified.

One-way repeated ANOVAs found that average levels of support for offenders with specific correctional histories differed significantly on both types of employment items, proximity $F(5,12630)=907.35, p<.001$, and policy, $F(4,11112)=444.12, p<.001$. Similarly, average support scores differed across correctional history levels at both levels of housing questioning, proximity $F(5.35,12601.55)=790.63, p<.001$, and policy $F(4$, $11572)=306.51, p<.001$. What is notable, however, is that (unlike the type of crime variables), some conditions in the 'correctional history' items actually produced higher levels of comfort and support among respondents. This indicates that there is some belief in the redemptive effects of certain forms of correctional response (ie, rehabilitation programs and other education and training).

Finally, the effect of an offender's personal characteristics on community acceptance was examined. Table 7 presents the means and standard deviations for levels of support when this additional information was provided.

\section{Table 7}

Levels of support for housing and employment (at the proximity and policy levels) when details about the offender were provided

\begin{tabular}{|c|c|c|c|c|}
\hline & \multicolumn{2}{|c|}{$\begin{array}{c}\text { Proximity - } \\
\text { Comfort about potential } \\
\text { contact }\end{array}$} & \multicolumn{2}{|c|}{$\begin{array}{c}\text { Policy - } \\
\text { Support for gov't } \\
\text { policies }\end{array}$} \\
\hline & $\mathrm{M}$ & $S D$ & M & $S D$ \\
\hline $\begin{array}{l}\text { Support for employment } \\
\text { when personal } \\
\text { characteristics not } \\
\text { specified }\end{array}$ & 3.88 & 1.55 & 4.76 & 1.83 \\
\hline \multicolumn{5}{|l|}{$\begin{array}{l}\text { Support for employment } \\
\text { when personal } \\
\text { characteristics specified }\end{array}$} \\
\hline Remorseful & *4.64 & 1.77 & ${ }^{*} 5.10$ & 1.82 \\
\hline Motivated not to reoffend & 4.60 & 1.78 & ${ }^{*} 5.12$ & 1.82 \\
\hline
\end{tabular}




\begin{tabular}{|l|c|c|c|c|}
\hline Parent & 3.85 & 1.70 & 4.81 & 1.86 \\
\hline Aged 17 or under & 3.84 & 1.73 & 5.00 & 1.84 \\
\hline Aged 31-40 & 3.51 & 1.67 & 4.55 & 1.86 \\
\hline $\begin{array}{l}\text { Support for housing when } \\
\text { personal characteristics } \\
\text { not specified }\end{array}$ & 3.33 & 1.54 & 4.15 & 1.88 \\
\hline $\begin{array}{l}\text { Support for housing when } \\
\text { personal characteristics } \\
\text { specified }\end{array}$ & & & & \\
\hline Remorseful & 4.35 & 1.77 & 4.64 & 1.92 \\
\hline Motivated not to reoffend & 3.48 & 1.78 & $* 4.66$ & 1.91 \\
\hline Parent & 3.38 & 1.70 & 4.46 & 1.95 \\
\hline Aged 17 or under & 3.11 & 1.65 & 3.95 & 1.90 \\
\hline Aged 31-40 & & & & \\
\hline
\end{tabular}

* The highest means

The public's average level of support and comfort in relation to the employment of offenders with different personal characteristics differed significantly, both in relation to working with offenders $F(5,11841)=620.9$, $p<.001$, and support for policies to enhance their employment prospects on release $F(5,12096)=259.2, p<.001$. The findings for housing were similar, with significant differences for both proximity, $F(4,10705)=737.2, p<.001$, and for policy being found $F(5,14283)=301.22, p<.001$.

Again, as with the other results, the public's level of support for both housing and employment related initiatives for offenders exceeds their level of comfort about living near or working with offenders. Also notable is that, again, there are offender characteristics that make the community more amenable to such ideas than they are in the hypothetical (ie, when no offender details are presented). As is evident from Table 7, being remorseful and motivated to cease offending are seen as significant positives by a community that is clearly making assessments of eligibility.

\section{Discussion}

This paper began by observing that current rehabilitative and punitive efforts to reduce reoffending are not performing at levels that justify expenditure. This has contributed to a renewed interest in addressing re-offending at the broader psychosocial level, and a concomitant increase in programs such as housing and employment, which target post-release issues. Housing and 
employment are known to be correlates of re-offending, while also being systematically more difficult for people with criminal records to obtain and/or maintain. While policies and programs that acknowledge the importance of social correlates of crime are a logical and positive step in efforts to reduce reoffending, their primary tenet also holds the potential to be the biggest threat to their efficacy. By this, we refer to their emphasis on community action and reaction. If the community are not ready for, and actively supportive of, correctional efforts to reintegrate offenders, these initiatives are likely to fail. In this sense, the social aspects of reintegrative efforts mean that they rely on the community in ways that other correctional imperatives do not.

With this fundamental issue in mind, this paper first set out to identify the nature of legislative support for reintegrative endeavours. This informal audit was conducted because, without legislative frameworks and guidance, the judiciary, correctional services and the community are likely to be less aware of, and therefore focused on, the ethos underlying reintegration. The second and much larger component of the study measured the extent and nature of community support for reintegrative ideals at both the personal and policy level. Both sets of findings identified significant obstacles to the success of reintegrative programs and policies.

The audit of legal authority highlighted that reintegration per se is not included as a goal of sentencing for adult offenders in any Australian jurisdiction. Although reintegrative ideas appear in the texts, they are not named as such and there are examples of conceptual blurring of rehabilitative ideas and reintegrative ones. Policies and programs are unlikely to receive judicial support if the judiciary are not aware of the distinction between rehabilitation and reintegration, and if the legislation does not allow for reintegrative goals to be cited when delivering sentences. Without more concrete parameters and pathways, reintegrative programs are already at a serious disadvantage.

The community itself was identified as the second site of potential obstruction to reintegrative ideas, as it is there that reintegration must occur. Again, major obstacles emerged quickly. The findings indicated that the public rated the reintegrative goal the lowest of all listed sentencing objectives. We would argue that this is at least partly due to a lack of awareness of current reoffending patterns and of the potential for reintegration to meaningfully address the issue of reoffending. A positive finding in regard to community rankings of sentencing goals was that, rather than pure punishment, 'making the community safer' was the highest ranked objective. This suggests that, if the community could be shown that reintegrative programs have great 
potential to reduce reoffending (and thus increase safety), they may give increased levels of support.

This pattern in public rankings of correctional objectives is consistent with the many other studies that have investigated attitudes to crime. ${ }^{26}$ Consistent with the above argument, these studies have partly attributed a public tendency towards punitiveness to lack of knowledge about sentencing trends, and have shown that the public become less punitive when given additional information about particular crimes.

With regard to more specific aspects of the present survey, a number of trends were clearly evident. First, people were more likely to support employmentbased components of reintegration than housing-related aspects, and these differences between the two domains remained when further information about the offender's correctional history, offence and personal characteristics were provided. However, even though the public were more open to employment-based ideas (at the personal and policy level), the average level of support was moderate, being just above the mid point of the 7 point scale.

Second, support for either domain was lower at the personal involvement level than at the policy level. That is, people were more likely to support employment and housing at the policy level than they were to feel comfortable working with or living near an offender (the proximity level). The only exceptions to this occurred when offence type was provided. Participants reported less support for policies to assist offenders who had committed corporate, investment crimes, and fraud and embezzlement, than comfort about working with or living near such offenders. In other words, they were less happy about the government assisting these few offender groups, than they would be living near them. Again, the theme of safety emerges as a likely explanation here, as these offending groups represent little overt threat to personal safety. As further support for this safety-based interpretation, sex offenders were always the least accepted offender group in this survey, and this is likely to be due to well documented (but erroneous) ideas about this group being highly recidivistic. The 'not in my back yard' (NIMBY) phenomenon may also be of interpretive use, as it indicates that, in

\footnotetext{
${ }^{26}$ See, eg, Anthony Doob, 'Transforming the Punishment Environment: Understanding Public Views of What Should Be Accomplished at Sentencing' (2000) 42(3) Canadian Journal of Criminology 323; Mike Hough and Julian Roberts, Attitudes to Punishment: Findings from the British Crime Survey (Home Office Research and Statistics Directorate, 1998); David Indermaur and Lynne Roberts, 'Confidence in the Criminal Justice System' in Trends \& Issues in Crime and Criminal Justice No 387 (2009).
} 
many domains of society, the public has a sense of what is socially desirable at the policy level, but is much less willing to be personally involved. ${ }^{27}$

The third clear trend in the data was for respondents to be more accepting of offenders when information about their actual offence was absent. This was true in relation to both reintegrative domains, and at the policy and proximity levels. Even when the crime committed was minor and non-violent, respondents' acceptance scores dropped significantly in comparison to when the generic term 'offender' was used. This finding is unexpected and certainly warrants further investigation. It may be that, consistent with the NIMBY thesis, people wish to do good, but specifics erode this tendency. Again, the ramifications of that interpretation are not all negative for reintegrative endeavours.

The fourth set of findings related to the effect of providing information about correctional history and the personal characteristics of offenders. In both instances, there were examples where providing specific information improved the public's acceptance of the offender in comparison to the generically described 'offender'. In relation to correctional history, participants reported highest support for offenders who had experienced rehabilitation and/or education and training programs. The personal characteristics that prompted higher support levels were being remorseful and motivated not to re-offend. This latter set of findings again indicates some reason for hope. There are offender types (but not offence types) that the public are much more likely to be supportive of. As was the case in relation to the goals of sentencing, there is reason to believe that there is not general and holistic opposition to reintegrative ideas. Thus while these findings certainly highlight a set of conditions and qualifications that pose challenges, they do not indicate absolute opposition. The increased acceptance of offenders who are remorseful and/or motivated not to reoffend is further evidence of the imbedded ideas of eligibility and forfeiture.

These findings strengthen the argument that, while there is fertile ground for reintegration in relation to juveniles (at both the legislative and community level), the conditions for success with adult offenders exist, but are less evident. These findings repeatedly highlight the need to be strategic in the focus and placement of reintegrative programs. Further, evidence of success must be identified and communicated, as this will show the community that their primary goal of 'safety' can be met via such programs.

${ }^{27}$ Dear, above n 23; Martin and Myers, above n 24, 143-71. 
Legal and social education has an important role. In research, as in public education, desistance needs to be examined through a wider lens, one that takes in the broader social context in which offenders are encouraged to desist. There is an analogy with the 'readiness' model of offender rehabilitation. Much research has been devoted to the readiness of the offender for treatment ${ }^{28}$ but very little has been done on the readiness of the community to assist in the process. While this study represents a beginning, we need to explicate further the sites of readiness via the community readiness models currently being employed to assess and build a community's capacity to take social action. ${ }^{29}$ As Bazemore and Stinchcomb concluded, in the reintegration process 'the community is, at the same time, both a major stumbling block and a major resource'. ${ }^{30}$ The current findings reinforce this idea.

There is a need to investigate the characteristics of specific communities and attitudes to reintegration. While some of the challenges facing offenders returning to rural areas are similar to those in urban areas - for example, a lack of affordable housing and limited employment opportunities - other barriers are exacerbated due to distance from urban centres. For example, there can be limited treatment and other service providers in rural communities, and the lack of 'social privacy', where 'everyone knows everyone's business', can lead to labelling and stigma. ${ }^{31}$

Importantly, we must educate the community about the emerging theories of offender reintegration. For example, there is little knowledge, beyond academic contexts, of established and emerging reintegrative theories such as reintegrative shaming ${ }^{32}$ and the Good Lives Model. ${ }^{33}$ The media too has a role

${ }^{28}$ See, eg, Tony Ward, Andrew Day, Kevin Howells and Astrid Birgden, 'The Multifactor Offender Readiness Model' (2004) 9(6) Aggression \& Violent Behavior 645.

${ }^{29}$ See, eg, Kathleen Kelly, Ruth Edwards, Maria Leonora Comello, Barbara Plested, Pamela Jumper-Thurman and Michael Slater, 'The Community Readiness Model: A Complementary Approach to Social Marketing' (2003) 3(4) Marketing Theory 411; Michael Slater, Kathleen Kelly and Ruth Edwards, 'Integrating Social Marketing, Community Readiness and Media Advocacy in Community-Based Prevention Efforts' (2000) 6(3) Social Marketing Quarterly 125 .

${ }^{30}$ Gordon Bazemore and Jeanne Stinchcomb, 'A Civic Engagement Model of Reentry: Involving Community through Service and Restorative Justice' (2004) 68(2) Federal Probation 14.

${ }^{31}$ Ralph Weisheit and Edward Wells, 'Rural Crime and Justice: Implications for Theory and Research' (1996) 42(3) Crime \& Delinquency 384.

32 John Braithwaite, 'Shame and Criminal Justice' (2000) 42(3) Canadian Journal of Criminology 281.

${ }^{33}$ Tony Ward and Mark Brown, 'The Good Lives Model and Conceptual Issues in Offender Rehabilitation' (2004) 10(3) Psychology, Crime \& Law 243. 
in educating the community about the social conditions that promote desistance.

Finally there is an urgent need to thoroughly audit the post release services and programs being delivered in Australian jurisdictions. The lack of consistent definition and clear theoretical underpinnings is reflected in the general definitional 'fogginess' evident in the legislature. This is difficult to change, but, in the face of such ambiguity, there is an immediate need to ascertain what policy makers understand by reintegration before work can be done on educating the community to accept its role in it. 